\title{
28. OLIGOCENE-PLEISTOCENE CALCAREOUS NANNOFOSSILS FROM SOUTHERN OCEAN SITES 747, 748, AND 751 ${ }^{1}$
}

\author{
Wuchang Wei ${ }^{2,3}$ and Sherwood W. Wise, Jr. ${ }^{2}$
}

\begin{abstract}
Detailed calcareous nannofossil range charts for the Oligocene-Pleistocene sections from high-latitude Ocean Drilling Program Sites 747, 748, and 751 in the southern Indian Ocean are presented in this report. Calcareous nannofossils are generally low in abundance in Pliocene-Pleistocene sediments, whereas they are very abundant throughout the Miocene and Oligocene. Species diversity, however, is low compared with assemblages in the lower latitudes. Nannofossil reworking is extensive in the middle Miocene at Site 751, less extensive in the lower Miocene at Site 748, and negligible for the entire Neogene at Site 747. Six nannofossil datums, which have previously been correlated with magnetostratigraphy in the Southern Ocean, were recognized in the upper Oligocene-Pleistocene sequence at Site 747. Three such nannofossil datums are available for the Neogene at Sites 748 and 751 . A new subspecies, Coccolithus pelagicus floralis, is described.
\end{abstract}

\section{INTRODUCTION}

Neogene calcareous nannofossils were recovered only at three sites (747, 748, and 751) from Ocean Drilling Program (ODP) Leg 120 (Fig. 1). However, these assemblages provide an important bridge between those sampled between $50^{\circ}$ and $52^{\circ} \mathrm{S}$ during ODP Legs 114 and 119 , and those from $63^{\circ}$ and $65^{\circ} \mathrm{S}$ recovered during Legs 113 and 119 (Ciesielski, Kristoffersen, et al., 1988; Barron, Larsen, et al., 1989; Barker, Kennett, et al., 1988). As such, the Leg 120 sites provide a unique sequence of transitional sites across which changes in the diversity and composition of nannofossil assemblages can be traced in reference to latitude.

Located well south of the present-day Polar Front, the Leg 120 sites studied lie at fairly shallow depths (water depths range from 1298 to $1634 \mathrm{~m}$ ), and primarily for this reason Leg 120 succesfully recovered for the first time long sequences of Pliocene-Pleistocene carbonate sediments at these high latitudes (Schlich, Wise, et al., 1989). Among the 11 sites drilled on the Kerguelen Plateau during Legs 119 and 120, Hole 751A was a dedicated Neogene site chosen specifically to yield an expanded carbonate-rich section, at least for the Miocene. The expected high sedimentation rates would provide the basis for a high-resolution biostratigraphy, magnetostratigraphy, and chemostratigraphy of these high-latitude sites.

This report provides a description of the distribution of the Neogene nannofossil assemblages recovered at Sites 747, 748, and 751. Extensive Neogene sediments were recovered in only one hole at each site. The range chart for Hole 747A was extended down into the upper Oligocene to link up with the distribution chart for Paleogene assemblages (Aubry, this volume) for that site. Additional discussion and interpretation of the Neogene nannofossil assemblages, key datums, and their correlations with magnetostratigraphy at theses sites as well as at other Southern Ocean sites are given in Wei and

\footnotetext{
${ }^{1}$ Wise, S. W., Jr., Schlich, R., et al., 1992. Proc. ODP, Sci. Results, 120: College Station, TX (Ocean Drilling Program). U.S.A.

Department of Geology, Florida State University, Tallahassee, FL 32306,

${ }^{3}$ Present address: Geological Research Division, Scripps Institution of Oceanography, University of California, San Diego, La Jolla, CA 92093, U.S.A.
}

Wise (this volume) and in Harwood et al. (this volume). Leg 120 Paleogene nannofossil assemblages are discussed by Aubry (this volume) and Wei et al. (this volume).

\section{MATERIALS AND METHODS}

Smear slides were made directly from unprocessed samples and were routinely examined using a light microscope at magnifications of either $\times 650$ or $\times 1330$ (for the identification of small coccoliths such as Emiliania huxleyi in the latter case). At the lower magnification, the abundance of calcareous nannofossils in each slide was estimated using the following criteria: $\mathrm{V}=$ very abundant (more than 10 specimens per field of view); $\mathrm{A}=$ abundant (1-10 specimens per field of view; $\mathrm{C}=$ common ( 1 specimen per $2-10$ fields of view); $\mathrm{F}=$ few (1 specimen per $11-50$ fields of view); $\mathrm{R}=$ rare $(1$ specimen per 51-200 fields of view); and $\mathrm{B}=$ barren (no specimen was found in 200 fields of view). Preservation of the calcareous nannofossil assemblage is recorded as $\mathrm{G}=$ good (little evidence of etching or overgrowth); $\mathrm{M}=$ moderate (etching or overgrowth is apparent); and $\mathrm{P}=$ poor (there is significant etching or overgrowth and identification of some species is impaired).

Calcareous nannofossil species considered in this paper are listed in the Appendix and are arranged alphabetically by generic epithets. Bibliographic references for these taxa can be found in Loeblich and Tappan (1966, 1968, 1969, 1970a, 1970b, 1971, 1973), Heck (1979a, 1979b, 1980a, 1980b, 1981a, 1981b, 1982a, 1982b, 1983), or Steinmetz (1985a, 1985b, 1986, 1987a, 1987b, 1988a, 1988b, 1989). Stratigraphically important occurrences and selected species are illustrated in Plates 1 and 2.

The upper Oligocene is zoned using the high-latitude nannofossil zonation of Wei and Thierstein (1991). The last occurrences (LOs) of Reticulofenestra bisecta and Chiasmolithus altus used for subdivision of the upper Oligocene have previously been correlated with magnetostratigraphy (Wei and Wise, 1989, 1990) and Wei and Thierstein (1991). For reference to lower latitude stratigraphies, combined Neogene zones are tentatively indicated according to the zonation of Okada and Bukry (1980). Most of the index taxa of Okada and Bukry (1980) are absent at these high latitudes, but a few nontraditional datums are useful for stratigraphic subdivision at these sites. These nontraditional datums include the LO of 


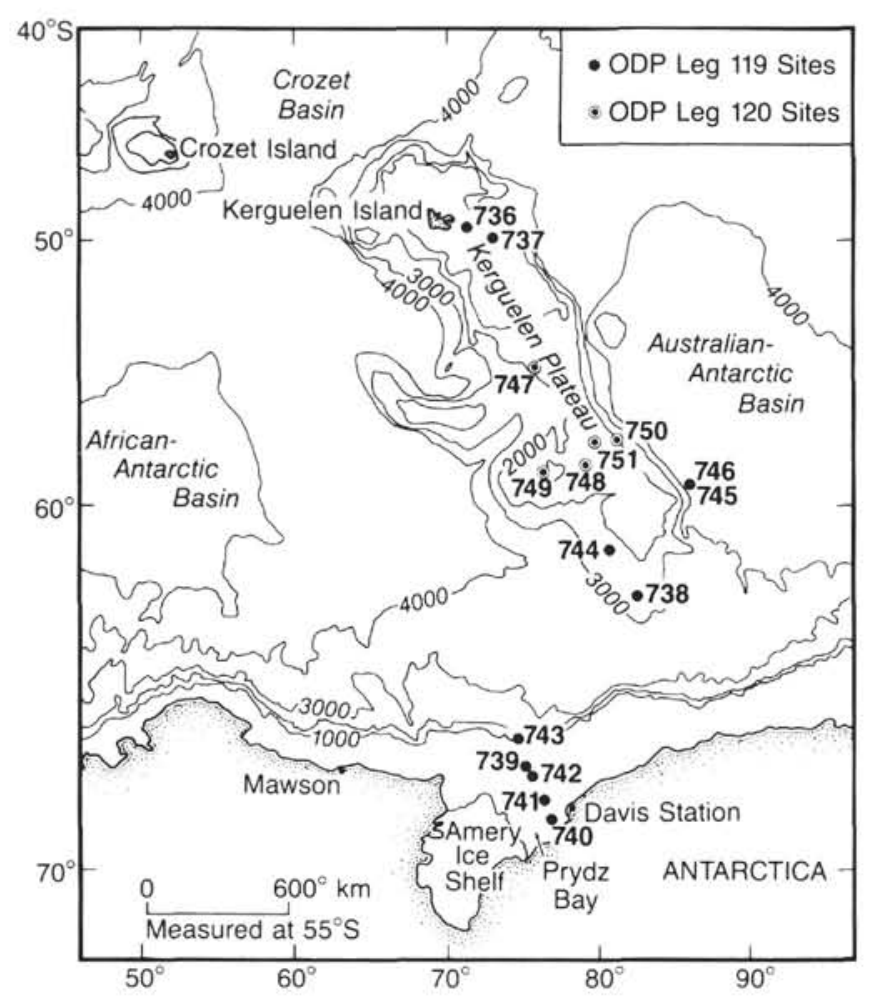

Figure 1. Location map of Leg 120 sites.

Reticulofenestra gelida, the LO of Reticulofenestra hesslandii, and the FO of Calcidiscus leptoporus/C. macintyrei.

\section{HOLE DESCRIPTIONS}

\section{Hole 747A}

Site 747 is located in the transition zone between the northern and southern parts of the Kerguelen Plateau, approximately $500 \mathrm{~km}$ south of the Polar Front, at $54^{\circ} 48.68^{\prime} \mathrm{S}$, $76^{\circ} 47.64^{\prime} \mathrm{E}$ (Fig. 1) in a water depth of $1697 \mathrm{~m}$. The PliocenePleistocene sequence recovered consists of foraminifer diatom oozes with minor ice-rafted debris (IRD) and dropstones and sporadic vitric ash layers throughout. The Miocene to upper Oligocene section is a nannofossil ooze with some vitric ash layers.

The Oligocene-Pleistocene calcareous nannofossil distribution in Hole 747A is presented in Table 1. The abundance of calcareous nannofossils is generally low in the PliocenePleistocene section, but consistently high throughout the Miocene-Oligocene section. Preservation of the nannofossils is generally moderate, with apparent overgrowth on most of the specimens. Nannofossil diversity in the sequence studied is low compared with lower latitudes. None of the Discoaster marker species used in the low latitudes for the subdivision of the Pliocene was found. Almost none of the traditional nannofossil datums for the Neogene are applicable because of their absence or scarcity. The biostratigraphic resolution is, therefore, quite low for the Neogene section. Nevertheless, several nannofossil datums have been identified in the Oligocene-Pleistocene sequence that provide useful data for constructing age-depth curves.

Common to abundant Emiliania huxleyi were found in Samples 120-747A-1H-1, 58-62 cm (Plate 1, Figs. 1 and 2) and $-1 \mathrm{H}-2,10-11 \mathrm{~cm}$, but not in Sample 120-747A-1H-3, 59-62 $\mathrm{cm}$, in which nannofossils are common. The first occurrence (FO) of E. huxleyi is, therefore, placed between Samples
$120-747 \mathrm{~A}-1 \mathrm{H}-2,10-11 \mathrm{~cm}$, and $-1 \mathrm{H}-3,58-62 \mathrm{~cm}$. This datum defines the CN14/CN15 zonal boundary (Okada and Bukry, 1980 ) and has an age of $0.275 \mathrm{Ma}$ (Berggren et al., 1985).

No Gephyrocapsa were noted within this zone, although this genus is represented in the subjacent samples. Assuming that the zonation of Gartner (1977) can be applied at this high latitude, these two samples with high abundances of $E$. huxleyi to the the virtual exclusion of other taxa would fall into Gartner's Emiliania huxleyi Acme Zone, which is dated roughly as 0-70,000 yr (Gartner, 1977; Thierstein et al., 1977). The true age of this zone at this high latitude, however, could be different from that at lower latutides because of the tolerance of $E$. huxleyi for lower temperatures relative to other taxa. Detailed studies are necessary to date this zone more precisely in this region, which lies at a considerably higher latitude than any of the Southern Hemisphere cores analyzed by Thierstein et al. (1977).

The last occurrence (LO) of Reticulofenestra gelida is between Sample 120-747A-3H-2, 58-62 cm, and -3H-3, 34-36 $\mathrm{cm}$. This datum has been calibrated with magnetostratigraphy at ODP Site 744 on the Southern Kerguelen Plateau at about 3.8 Ma (Wei and Thierstein, 1991; Barron et al., 1991), very close to the age of the LO of Reticulofenestra pseudoumbilica (3.5 Ma; Berggren et al., 1985). This is not surprising because $R$. gelida differs from $R$. pseudoumbilica mainly in its smaller central opening, and many workers consider the former species to be a junior synonym of the latter (see detailed discussion by Backman, 1980; Wise, 1983; Perch-Nielsen, 1985). Specimens of typical $R$. pseudoumbilica were found only in the lower Miocene in this hole. The LO of $R$. gelida is used here to delimit the $\mathrm{CN} 11 / \mathrm{CN} 12$ zonal boundary.

The LO of Reticulofenestra hesslandii was recognized between Samples 120-747A-7H-4, 10-11 cm, and -7H-5, $58-62 \mathrm{~cm}$. This datum occurs at $\sim 11.1 \mathrm{Ma}$, as calibrated with magnetostratigraphy at Site 744 (Wei and Thierstein, 1991; Barron et al., 1991), an age similar to that of the LO of Cyclicargolithus floridanus at lower latitudes (11.6 Ma; see further discussion by Wei and Wise, this volume).

The FO of Calcidiscus leptoporus/C. macintyrei was placed between Samples 120-747A-11H-1, 58-62 cm, and $-11 \mathrm{H}-2,10-11 \mathrm{~cm}$. This datum has been correlated with magnetic Chron C5D ( 18.2 Ma) at Site 744 (Wei and Thierstein, 1991; Barron et al., 1991), and is a useful datum in the southern Indian Ocean (Wei and Wise, this volume).

The LO of Reticulofenestra bisecta was located between Samples $120-747 \mathrm{~A}-14 \mathrm{H}-4,58-62 \mathrm{~cm}$, and $-14 \mathrm{H}-5,10-12 \mathrm{~cm}$. The rare higher occurrences of this species (Samples 120$747 \mathrm{~A}-14 \mathrm{H}-2,10-12 \mathrm{~cm}$, and $-14 \mathrm{H}-4,10-12 \mathrm{~cm}$ ) are considered reworked. Except in the extreme high latitudes, such as at Site 690 in the Weddell Sea, where the species is very rare or virtually absent in the upper Oligocene, the LO of R. bisecta can be used to mark the Oligocene/Miocene boundary in the mid to high latitudes, where it has a magnetostratigraphically calibrated age of about 24.0 Ma (Wei and Wise, 1989; Wei and Thierstein, 1991).

Very abundant Chiasmolithus altus were first encountered downhole in Sample 120-747A-16H-1, 10-12 cm. The overlying sample $(120-747 \mathrm{~A}-15 \mathrm{H}-7,10-12 \mathrm{~cm})$ contains only few specimens of $C$. altus. These and other rare occurrences in higher samples are considered reworked. The LO of $C$. altus has an estimated age of about $27.2 \mathrm{Ma}$, based on its biomagnetostratigraphic correlation at Site 744 (Wei and Thierstein, 1991; Barron et al., 1991).

No in-situ Reticulofenestra umbilica or Isthmolithus recurvus were found in the sequence examined. Core 120-747A$17 \mathrm{H}$, therefore, is younger than $33.0 \mathrm{Ma}$, the age for the LO of $R$. umbilica as calibrated by magnetostratigraphy at a number 
of Southern Ocean sites (Wei and Wise, 1990, and unpubl. data).

The datum levels that are useful for constructing age-depth curves (Harwood et al., this volume) are summarized in Table 2. Although most of these datums are not zonal/subzonal markers in the zonations of Martini (1971) or Okada and Bukry (1980), they have proven to be useful for nannofossil biostratigraphy in the Southern Ocean. A formal zonation using these datums will be described elsewhere.

\section{Holes 748A and 748B}

Site 748 is located on the Southern Kerguelen Plateau in the western part of the Raggatt Basin, east of Banzare Bank at $58^{\circ} 26.45^{\prime} \mathrm{S}, 78^{\circ} 58.89^{\prime} \mathrm{E}$ (water depth $=1290 \mathrm{~m}$ ). The site was intended to recover an expanded section of Paleogene and Cretaceous sediments; it also proved to be valuable in that it yielded a reasonably complete Pleistocene to upper Eocene section not interrupted by chert beds. Full core recovery in the upper $180 \mathrm{~m}$ of the section in Hole $748 \mathrm{~B}$ provided an excellent Neogene calcareous-biosiliceous sequence with good paleomagnetic control (Inokuchi and Heider, this volume); thus, this site is especially valuable for high-latitude biostratigraphic and magnetostratigraphic correlation.

The Pliocene-Pleistocene sequence consists of diatom ooze with radiolarian and foraminifer-enriched intervals, dropstones, and IRD. The Miocene to upper Oligocene sediments are nannofossil ooze with biosiliceous enriched intervals.

Hole $748 \mathrm{~A}$ recovered two cores before it was terminated. The first two sections are barren of calcareous nannofossils (Table 3); this indicates that the Emiliania huxleyi Zone (CN15) was not recovered. Rare Reticulofenestra perplexa were found in Sections 120-748A-1H-3 and -2H-2, along with Coccolithus pelagicus and rare specimens of apparently reworked Paleogene species. These occurrences of $R$. perplexa are probably reworked; otherwise, they would be the youngest ( $\sim 3 \mathrm{Ma}$ according to Harwood et al., this volume) ever reported in the Southern Ocean.

The LO of Reticulofenestra gelida was recorded in Sample 120-748A-2H-3, 90-94 cm. Very abundant Coccolithus pelagicus and Reticulofenestra perplexa were also first encountered in this sample, coincident with the lithologic boundary between siliceous and calcareous ooze.

Table 4 provides a detailed documentation of the Neogene calcareous nannofossil distribution in Hole 748B. Reticulofenestra gelida was first encountered in Sample 120-748B$2 \mathrm{H}-7,58-62 \mathrm{~cm}$. As the overlying samples are barren of calcareous nannnofossils, the uppermost portion of the range of $R$. gelida could have been truncated by this barren interval. The $\mathrm{CN} 11 / \mathrm{CN} 12$ boundary is, therefore, tentatively placed between Samples 120-748B-2H-5, 58-62 cm, and $-2 \mathrm{H}-7$, $58-62 \mathrm{~cm}$.

The highest occurrence of of Reticulofenestra hesslandii is between Samples 120-748B-5H-7, $10 \mathrm{~cm}$, and -5H-7, 58-62 $\mathrm{cm}$, and thus an age of 11.1-11.6 Ma can be assigned to Sample 120-748B-5H-7, 58-62 cm. The FO of Reticulofenestra perplexa is also located in this sample, where the species is abundant. Elsewhere, the ranges of $R$. hesslandii and $R$. perplexa overlap for about $2 \mathrm{~m}$.y. It can be inferred that a disconformity exists in the vicinity of Sample 120-748B$5 \mathrm{H}-7,58-62 \mathrm{~cm}$. This is in agreement with the siliceous biostratigraphy and magnetostratigraphy interpretations of Harwood et al. (this volume), who placed a disconformity at the very top of Core $120-748 \mathrm{~B}-6 \mathrm{H}$.

The FO of Calcidiscus leptoporus was recognized between Samples $120-748 \mathrm{~B}-6 \mathrm{H}-3,58-62 \mathrm{~cm}$, and $-6 \mathrm{H}-4,58-62 \mathrm{~cm}$. This datum (as $C$. macintyrei) is used here to define the $\mathrm{CN} 3 / \mathrm{CN} 4$ zonal boundary at about $18.2 \mathrm{Ma}$.
In-situ Paleogene calcareous nannofossils are not present until Core 120-748B-9H (Aubry, this volume). Rare specimens of reworked upper Paleogene nannofossils, such as Chiasmolithus altus and Reticulofenestra umbilica, however, occur in almost every sample from Cores $12-748 \mathrm{~B}-6 \mathrm{H}$ through $-8 \mathrm{H}$. This indicates that active bottom currents persisted throughout the early Miocene at Site 748 .

Table 5 summarizes the Neogene nannofossil datums recognized at Site 748. Estimated ages are also given based on their correlations with magnetostratigraphy at other Southern Ocean sites.

\section{Hole 751A}

Site 751 lies on the Southern Kerguelen Plateau at $57^{\circ} 43.56^{\prime} \mathrm{S}, 79^{\circ} 48.89^{\prime} \mathrm{E}$ (water depth $=1633.8 \mathrm{~m}$ ) in the central part of the Raggatt Basin. The Pliocene-Pleistocene interval consists of diatom ooze with minor IRD, calcareous nannofossils, foraminifers, volcanic ash, and porcellanite. The Miocene sequence is diatom nannofossil ooze, but diatoms occur in equal or greater abundance than calcareous nannofossils in some stratigraphic intervals.

The calcareous nannofossil distribution in Hole $751 \mathrm{~A}$ is presented in Table 6 . Similar to Sites 747 and 748, calcareous nannofossils are generally rare or absent in the PliocenePleistocene and are very abundant throughout the Miocene. Preservation of the nannofossil assemblages is moderate in this hole. Most traditional marker species are absent or too rare to be useful for biostratigraphy at this site.

No Emiliania huxleyi was found in the first core. Sediments younger than Zone CN15 $(0.275 \mathrm{Ma})$, therefore, were not recovered in this hole. Abundant nannofossils were first encountered in Sample 120-751A-5H-6, 5-7 cm. This sample contains Reticulofenestra gelida and is, therefore, older than $3.8 \mathrm{Ma}$. The LO of Cyclicargolithus floridanus/Reticulofenestra hesslandii is between Samples 120-751A-11H-6, 5-7 cm, and -11H-7, 5-7 cm. This datum is about $11.1-11.6 \mathrm{Ma}$ as previously described above. The FO of Calcidiscus leptoporus/C. macintyrei was recognized between Samples 120-751A-16H-7, 2-4 cm, and $-17 \mathrm{H}-1,22-25 \mathrm{~cm}$. This datum is about $18.2 \mathrm{Ma}$ old and defines the $\mathrm{CN} 3 / \mathrm{CN} 4$ zonal boundary.

In-situ Oligocene assemblages are absent in this hole, and the oldest sediment from the hole is, therefore, younger than $24.0 \mathrm{Ma}$ (Oligocene/Miocene boundary). The nannofossil datums recognized in this hole that are useful for constructing age depth curves (Hardwood et al., this volume) are summarized in Table 7.

It is interesting to note that nannofossil reworking is significantly more extensive at this site than at Sites 747 and 748. Reworking is most severe in Cores $120-751 \mathrm{~A}-12 \mathrm{H}$ to $-16 \mathrm{H}$, a middle Miocene interval ( $\sim 11-17 \mathrm{Ma}$ according to Harwood et al., this volume). This is in contrast to Site 748, where more reworking was found in the lower Miocene. All the reworked nannofossils recognized at Site 751 are EoceneOligocene taxa. This extensive reworking and different patterns from other Kerguelen Plateau sites have important implications for water circulation patterns and current activities, which will be discussed elsewhere.

Magnetostratigraphies have been established for all the holes examined in this study (Inokuchi and Heider, this volume; Heider et al., this volume), and are shown in Tables 1,3 , and 6 along with the distribution of calcareous nannofossils. Consequently, the nannofossil datums have been correlated with the magnetostratigraphies, and their estimated ages at Site 747,748 , and 751 are given in Table 8 using the Berggren et al. (1985) time scale. More detailed discussions and comparisons of these ages with those at other Southern Ocean sites are treated elsewhere (Wei and Wise, this volume; Harwood et al., this volume). 
Table 1. Distribution of Oligocene-Pleistocene calcareous nannofossils in Hole 747A.

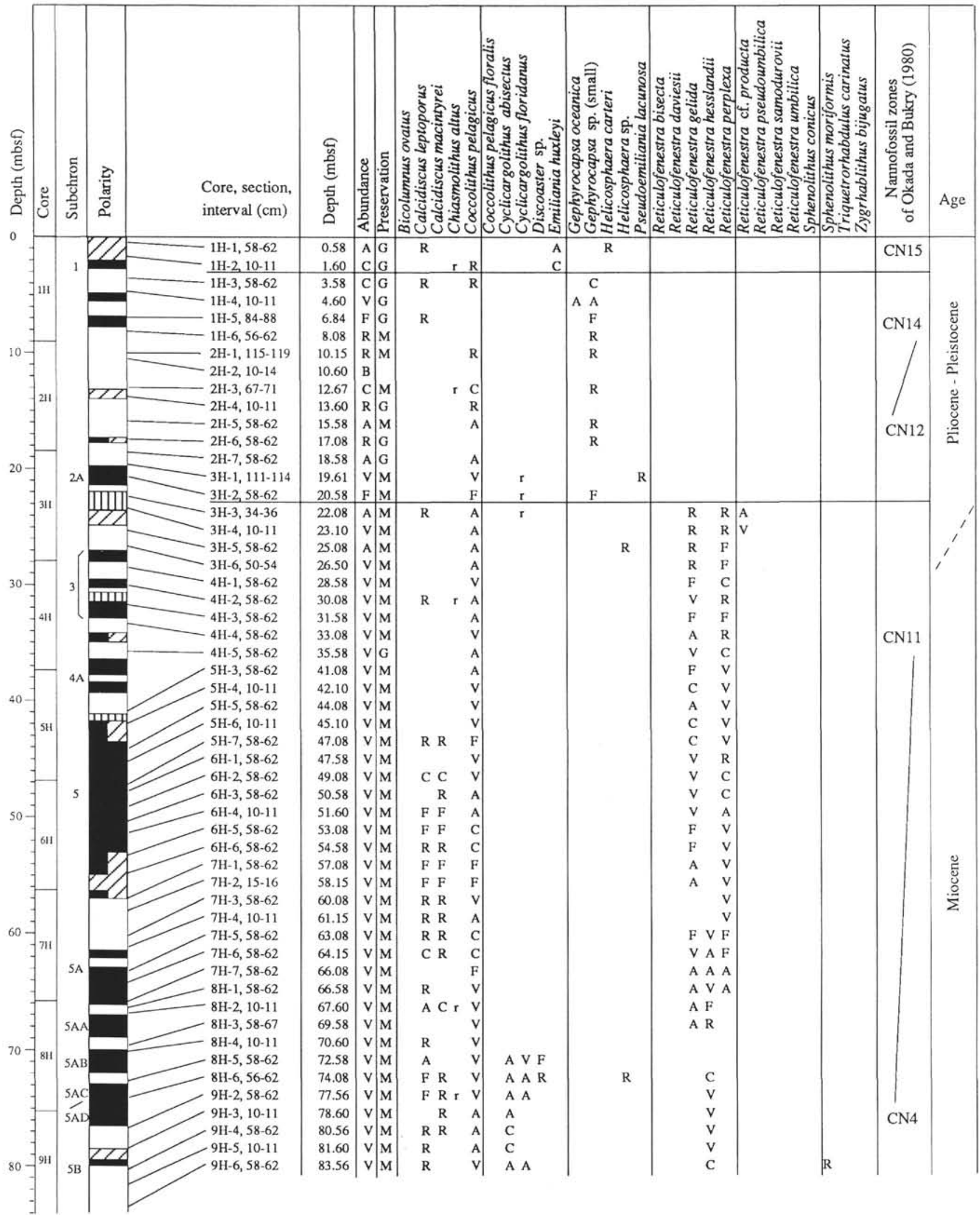

Notes: The high-latitude zonation of Wei and Thierstein (1991) is used for the upper Oligocene, and the zonation of Okada and Bukry (1980) is used for the Neogene. The abundance of calcareous nannofossils is characterized by $\mathrm{V}=$ very abundant, $\mathrm{A}=$ abundant, $\mathrm{C}=$ common, $\mathrm{F}=\mathrm{few}, \mathrm{R}=\mathrm{rare}, \mathrm{r}=$ rare reworked specimens, and $\mathrm{f}=\mathrm{few}$ reworked specimens. For preservation, $\mathrm{G}=$ good, $\mathrm{M}=$ moderate, and $\mathrm{P}=$ poor. Paleomagnetic data are taken from Heider et al. (this volume). Normal paleomagnetic subchrons are shown in black and reversed ones in white (those less reliable ones are shown in half columns). Data gaps are indicated by vertical lines and uninterpretable data by diagonal lines. 
Table 1 (continued).

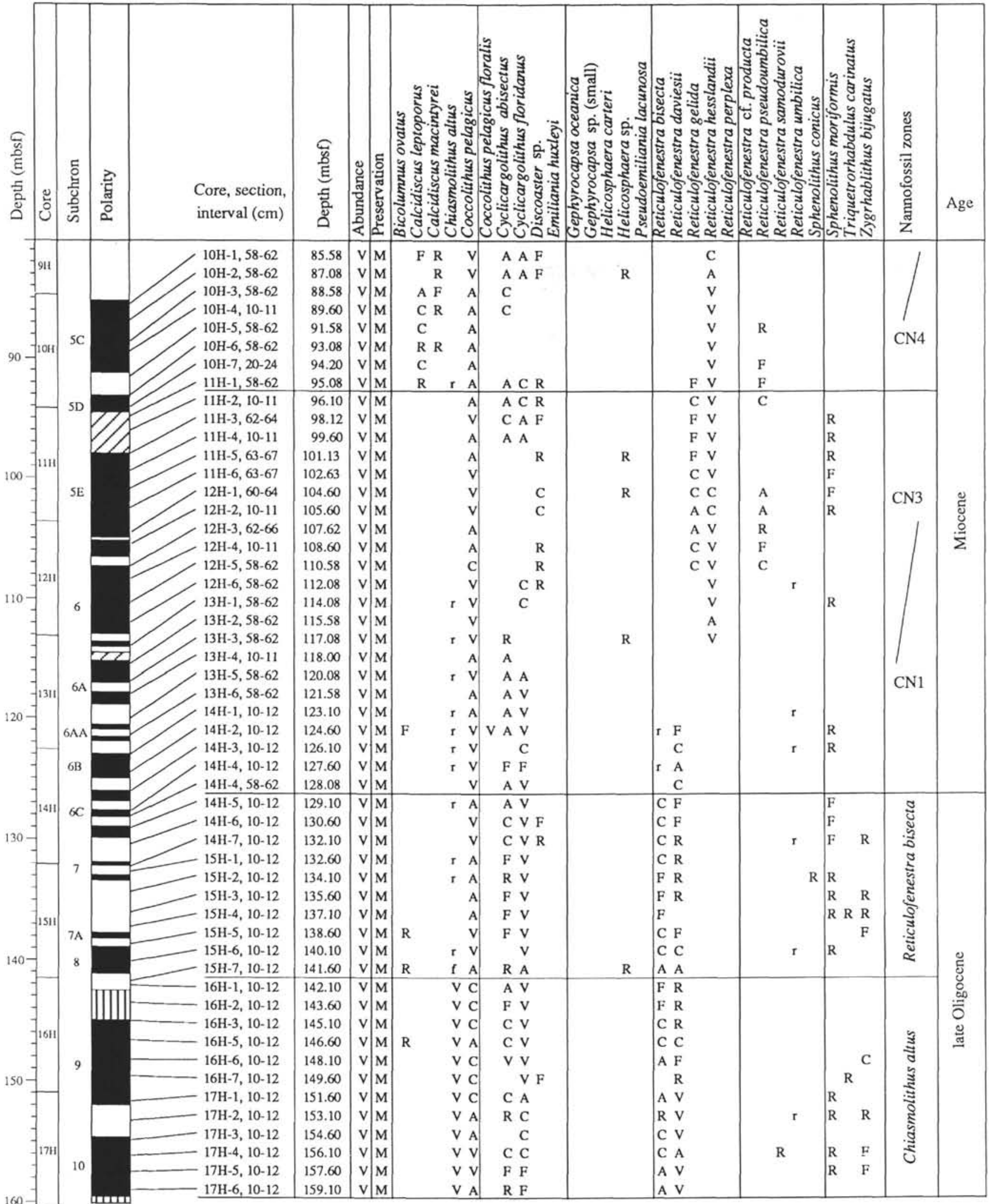


Table 2. Calcareous nannofossil datum levels in Hole 747 A and their estimated ages.

\begin{tabular}{llccc}
\hline \multicolumn{1}{c}{ Species event } & \multicolumn{1}{c}{$\begin{array}{c}\text { Core, section, } \\
\text { interval (cm) }\end{array}$} & Depth (mbsf) & $\begin{array}{c}\text { Age } \\
(\mathrm{Ma})\end{array}$ & Source \\
\hline FO Emiliania huxleyi & $1 \mathrm{H}-2,10 / 1 \mathrm{H}-3,58$ & $1.60-3.58$ & 0.275 & 1 \\
LO Reticulofenestra gelida & $3 \mathrm{H}-2,58 / 3 \mathrm{H}-3,34$ & $20.58-22.08$ & 3.8 & 2 \\
LO Reticulofenestra hesslandii & $7 \mathrm{H}-4,10 / 7 \mathrm{H}-5,58$ & $61.15-63.08$ & 11.1 & 2 \\
FO Calcidiscus leptoporus & $11 \mathrm{H}-1,58 / 11 \mathrm{H}-2,58$ & $95.08-96.10$ & 18.2 & 2 \\
LO Reticulofenestra bisecta & $14 \mathrm{H}-4,10 / 14 \mathrm{H}-5,10$ & $128.08-129.10$ & 24.0 & 3 \\
LO Chiasmolithus altus & $15 \mathrm{H}-7,10 / 16 \mathrm{H}-1,10$ & $141.60-142.10$ & 27.2 & 2 \\
\hline
\end{tabular}

Notes: 1 = Berggren et al. (1985); 2 = Wei and Thierstein (1991) and Barron et al. (1991); 3 = Wei and Wise (1989).

\section{SUMMARY AND CONCLUSIONS}

This report provides detailed calcareous nannofossil range charts for the Oligocene-Pleistocene sections from Sites 747, 748 , and 751 on the Kerguelen Plateau in the southern Indian Ocean. Six nannofossil datums that have previously been correlated with magnetostratigraphy in the Southern Ocean are recognized in the upper Oligocene-Pleistocene sequence at Site 747. Three such nannofossil datums are available for the Neogene at Sites 748 and 751 . These nannofossil datums provide useful age constraints for some stratigraphic intervals.

Calcareous nannofossils are generally low in abundance in the Pliocene-Pleistocene sediments, but very abundant throughout the Miocene and Oligocene. This indicates that surface-water temperatures during the Oligocene and Miocene were significantly higher than at present on the Kerguelen Plateau. Temperatures dropped below the tolerance levels of calcareous nannoplankton for much of Pliocene-Pleistocene time, when the Polar Front became established north of the study area. The presence of the uppermost Quaternary nannofossil marker species Emiliania huxleyi at Site 747 suggests that temperatures recovered sufficiently at some point during the last $70,000 \mathrm{yr}$ to allow this coccolith to thrive in this portion of the Southern Ocean. This rather recently evolved taxon is thought to have the widest temperature tolerance of all extant forms. In the Pacific Ocean, its distribution is bounded poleward by the summer position of the $0^{\circ} \mathrm{C}$ surfacewater isotherm (McIntyre et al., 1970).

Nannofossil reworking has been documented semiquantitatively. Reworking is quite extensive in the middle Miocene at Site 751, less extensive in the lower Miocene at Site 748, and negligible for the entire Neogene at Site 747. All reworked nannofossils recognized are of Eocene-Oligocene age. The different extent and patterns of reworking at different sites have important implications for water circulation patterns and current activities, a subject for future research.

\section{SYSTEMATIC PALEONTOLOGY}

Genus COCCOLITHUS Schwarz, 1894

Coccolithus pelagicus (Wallich) Schiller, 1930

Coccolithus pelagicus floralis Wei and Wise, n. ssp.

Plate 2, Figures 5-8

Coccolithus pelagicus (Wallich) Schiller, Wei and Wise, 1990, p. 662, pl. 2, figs. 8 and 9 .

Diagnosis. A subspecies of Coccolithus pelagicus with a calyx or crown or elements on the distal side that appears to project from the inner wall area. The calyx rises well above the distal shield to form what would otherwise be considered a third shield.

Description. This is an elliptical, medium-size coccolith in which the elements of the calyx number about 30 and correspond closely if not exactly to those of the proximal and distal shields. In the lateral view (Plate 2, Fig. 7), the height of the calyx may be equal to that of the proximal and distal shields combined. The width of the calyx is variable, but it may equal that of the proximal shield in some specimens (e.g., Plate 2, Fig. 7).
Table 3. Distribution of Miocene-Pleistocene calcareous nannofossils in Hole 748A.

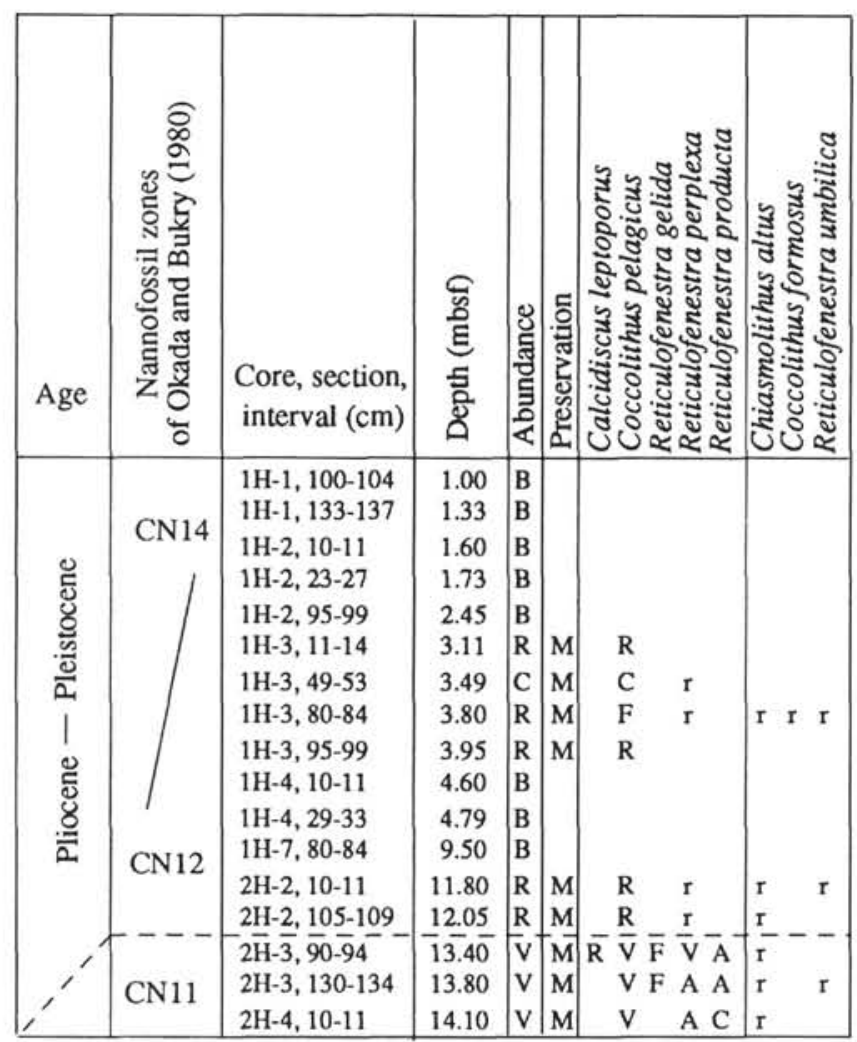

Notes: Nannofossil zones are given according to the zonation of Okada and Bukry (1980). The abundance of calcareous nannofossils is characterized by $\mathrm{V}=$ very abundant, $\mathrm{A}=$ abundant, $\mathrm{C}=$ common, $\mathrm{F}=$ few, $\mathrm{R}=$ rare, and $r=$ rare reworked specimens. For preservation, $\mathrm{M}=$ moderate.

Under crossed nicols, the distal shield is at extinction in plan view, whereas the proximal shield is birefringent. Specimens show a highorder yellow interference color in lateral view.

Remarks. Morphologically, this taxon superficially resembles some Paleogene heliolithids; however, the extinction pattern is that of Coccolithus. The specimens illustrated show some overgrowth, as do most specimens in the samples studied. It is possible that the calyx is strictly the product of overgrowth of the inner wall elements. However, the calyx rises to a uniform height and at a different angle from that of the inner wall elements, which would be remarkable if these were simply overgrowths. We think that if these specimens have been diagenetically altered, then the overgrowths must be rooted in a distinctively genetic morphologic feature, however obscure it may be. Coccolithus pelagicus has a long stratigraphic range (Paleocene to Holocene according to Bukry, 1973). The fact that the subspecies has been observed only from the lower-middle Miocene of Holes 329, 690B, 747 A, 748B, and 751A within otherwise uniform lithologies indicates that this morphology is not merely the result of random 
Table 4. Distribution of Miocene-Pleistocene calcareous nannofossils in Hole 748B.

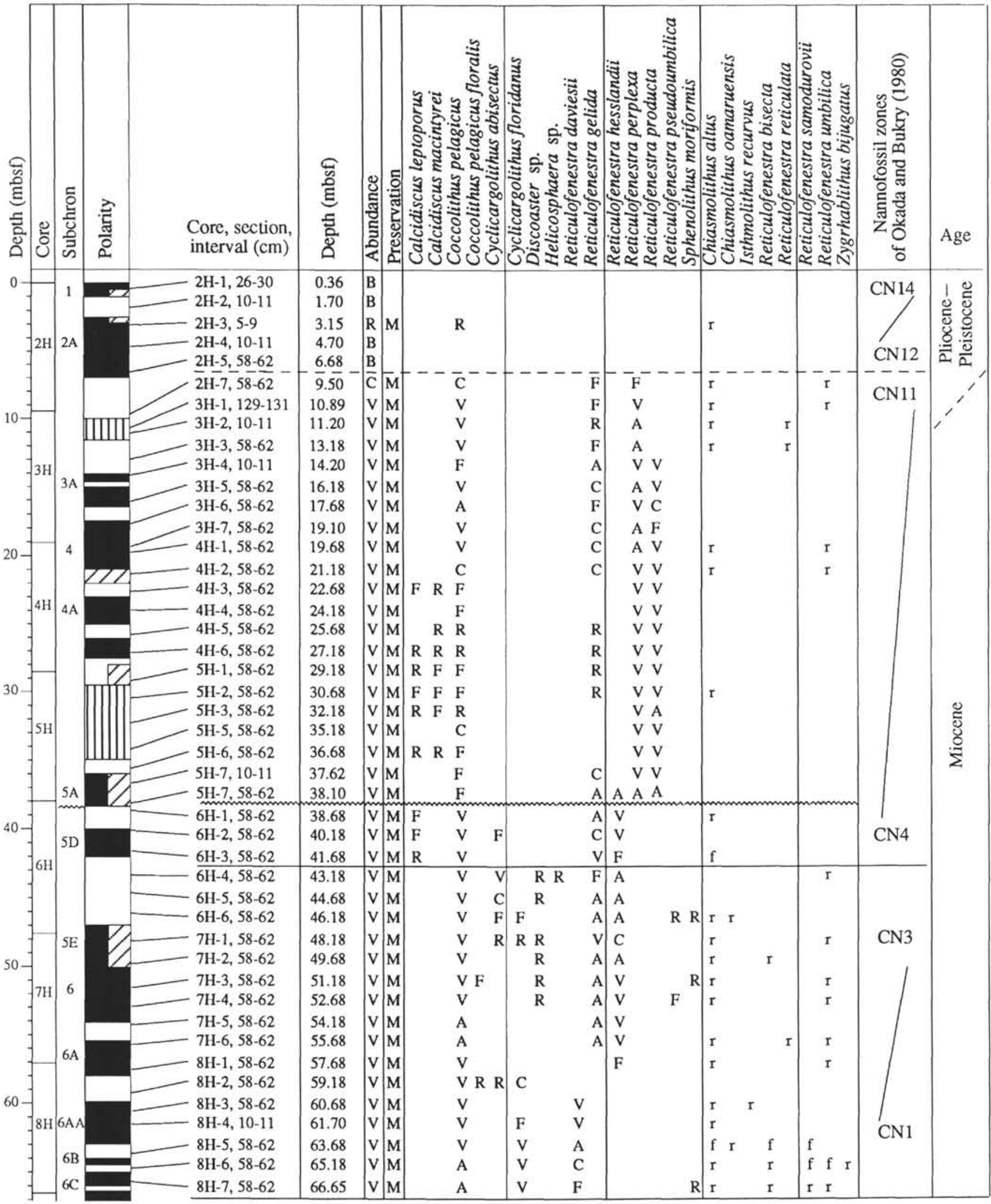

Notes: Nannofossil zones are given according to the zonation of Okada and Bukry (1980). Dashed lines indicate tentative zonal boundaries. Wavy lines denote disconformity. The abundance of calcareous nannofossils is characterized by $\mathrm{V}=$ very abundant, $\mathrm{A}=\mathrm{abundant}, \mathrm{C}=\mathrm{common}, \mathrm{F}=\mathrm{few}, \mathrm{R}=$ rare, $\mathrm{r}=$ rare reworked specimens, and $\mathrm{f}=$ few reworked specimens. For preservation, $\mathrm{M}=$ moderate and $\mathrm{P}=$ poor. Paleomagnetic data are taken from Heider et al. (this volume). Normal paleomagnetic subchrons are shown in black, and reversed ones in white (those less reliable ones are shown in half columns). Data gaps are indicated by vertical lines and uninterpretable data by diagonal lines. 
Table 5. Neogene calcareous nannofossil datum levels in Hole 748B and their estimated ages.

\begin{tabular}{lccrc}
\hline \multicolumn{1}{c}{ Species event } & $\begin{array}{c}\text { Core, section, } \\
\text { interval }(\mathrm{cm})\end{array}$ & Depth (mbs) & $\begin{array}{c}\text { Age } \\
(\mathrm{Ma})\end{array}$ & Source \\
\hline LO Reticulofenestra gelida & $2 \mathrm{H}-5,58 / 2 \mathrm{H}-7,58$ & $6.08-9.50$ & 3.8 & 1 \\
LO Reticulofenestra hesslandii & $5 \mathrm{H}-7,10 / 5 \mathrm{H}-7,58$ & $37.62-38.10$ & 11.1 & 1 \\
FO Calcidiscus leptoporus & $6 \mathrm{H}-3,58 / 6 \mathrm{H}-4,58$ & $41.68-43.18$ & 18.2 & 1 \\
\hline
\end{tabular}

Notes: 1 = Wei and Thierstein (1991) and Barron et al. (1991).

overgrowth. It has only been observed in sediments from the Southern Ocean.

Occurrence. Very abundant in Sample 120-747A-14H-2, 10-12 cm (lower Miocene). It has been figured by Wei and Wise (1990, plate 2 , figs. 8 and 9) under Coccolithus pelagicus for sediments from the middle Miocene at Sites 329 (Falkland Plateau) and 690 (Maud Rise). It was also found in the lower Miocene at Site 748 and in the middle Miocene at Site 751 .

Size. Holotype: $6 \mu \mathrm{m}$; isotypes: $6-8.5 \mu \mathrm{m}$.

Holotype. Plate 2, Figure 7.

Isotypes. Plate 2, Figures 5, 6, and 8 .

Type locality. Sample 120-747A-14H-2, 10-12 cm.

\section{ACKNOWLEDGMENTS}

We thank Drs. R. Constans, E. Joyce, and E. Thomas for critical reviews and many helpful suggestions. Mrs. Sandee Silverman assisted with SEM photography, and Sarah Wise helped with the preparation of the manuscript. This study was supported by NSF Grant No. DPP8917976, USSAC funds, and an equipment grant from the Amoco Foundation.

\section{REFERENCES}

Backman, J., 1980. Miocene-Pliocene nannofossils and sedimentation rates in the Hatton-Rockall Basin, NE Atlantic Ocean. Stockholm Contrib. Geol., 36:1-91.

Barker, P. F., Kennett, J. P., et al., 1988. Proc. ODP, Init. Repts., 113: College Station, TX (Ocean Drilling Program).

Barron, J. A., Baldauf, J. G., Barrera, E., Caulet, J.-P., Huber, B. T., Keating, B. H., Lazarus, D., Sakai, H., Thierstein, H. R., and Wei, W., 1991. Biochronologic and magnetochronologic synthesis of Leg 119 sediments from the Kerguelen Plateau and Prydz Bay, Antarctica. In Barron, J., Larsen, B., et al., Proc. ODP, Sci. Results, 119: College Station, TX (Ocean Drilling Program), 813-848.

Barron, J., Larsen, B., et al., 1989. Proc. ODP, Init. Repts., 119: College Station, TX (Ocean Drilling Program).

Berggren, W. A., Kent, D. V., and Flynn, J., 1985. Neogene geochronology and chronostratigraphy. In Snelling, N. J. (Ed.), The Chronology of the Geological Record: London (Geological Society), 211-260.

Bukry, D., 1973. Low-latitude coccolith biostratigraphic zonation. In Edgar, N. T., Saunders, J. B., et al., Init. Repts. DSDP, 15: Washington (U.S. Govt. Printing Office), 685-703.

Ciesielski, P. F., Kristoffersen, Y., et al., 1988. Proc. ODP, Init. Repts., 114: College Station, TX (Ocean Drilling Program).

Gartner, S., 1977. Calcareous nannofossil biostratigraphy and revised zonation of the Pleistocene. Mar. Micropaleontol., 2:1-25.

Loeblich, A. R., Jr., and Tappan, H., 1966. Annotated index and bibliography of the calcareous nannoplankton. Phycologia, 5:81-216.

1968. Annotated index and bibliography of the calcareous nannoplankton II. J. Paleontol., 42:584-598.

1969. Annotated index and bibliography of the calcareous nannoplankton III. J. Paleontol., 43:586-588.

1970a. Annotated index and bibliography of the calcareous nannoplankton IV. J. Paleontol., 44:585-574.

$1970 \mathrm{~b}$. Annotated index and bibliography of the calcareous nannoplankton V. Phycologia, 9:157-174. 1971. Annotated index and bibliography of the calcareous nannoplankton VI. Phycologia, 10:315-339. 1973. Annotated index and bibliography of the calcareous nannoplankton VII. J. Paleontol, 47:715-759.
Martini, E., 1971. Standard Tertiary and Quaternary calcareous nannoplankton. In Farinacci, A. (Ed.), Proceedings of the Second International Conference on Planktonic Microfossils, Roma, 1970: Rome (Ed. Technoscienza), 2:739-785.

McIntyre, A., Bé, A.W.H., and Roche, M. B., 1970. Modern Pacific Coccolithophorida: a paleontological thermometer. N. Y. Acad. Sci. Trans., Ser. II, 32:720-731.

Okada, H., and Bukry, D., 1980. Supplementary modification and introduction of code numbers to the low-latitude coccolith biostratigraphic zonation (Bukry 1973; 1975). Mar. Micropaleontol., 5:321-325.

Perch-Nielsen, 1985. Cenozoic nannofossils. In: Bolli, H. M., Saunders, J. B., and Perch-Nielsen, K. (Eds.), Plankton Stratigraphy: London (Cambridge University Press), 427-554.

Schlich, R., Wise, S. W., Jr., et al., 1989. Proc. ODP, Init. Repts., 120: College Station, TX (Ocean Drilling Program).

Steinmetz, J. C., 1985a. Bibliography and taxa of calcareous nannoplankton V. Int. Nannoplankton Assoc. Newsl., 7:5-28. 1985b. Bibliography and taxa of calcareous nannoplankton VI. Int. Nannoplankton Assoc. Newsl., 7:122-145. , 1986. Bibliography and taxa of calcareous nannoplankton VIII. Int. Nannoplankton Assoc. Newsl., 8:66-87. 1987a. Bibliography and taxa of calcareous nannoplankton IX. Int. Nannoplankton Assoc. Newsl., 9:8-29. 1987b. Bibliography and taxa of calcareous nannoplankton X. Int. Nannoplankton Assoc. Newsl., 10:81-109. 1988a. Bibliography and taxa of calcareous nannoplankton XI. Int. Nannoplankton Assoc. Newsl., 10:7-29. 1988b. Bibliography and taxa of calcareous nannoplankton XII. Int. Nannoplankton Assoc. Newsl., 10:60-88.

1989. Bibliography and taxa of calcareous nannoplankton XIII. Int. Nannoplankton Assoc. Newsl., 11:6-23.

Thierstein, H. R., Geitzenauer, K. R., Molfino, B., and Shackleton, N. J., 1977. Global synchroneity of late Quaternary coccolith datum levels: validation by oxygen isotopes. Geology, 5:400-404.

van Heck, S. E., 1979a. Bibliography and taxa of calcareous nannoplankton. Int. Nannoplankton Assoc. Newsl., 1:AB1-5, A1-12, B1-27.

1979b. Bibliography and taxa of calcareous nannoplankton. Int. Nannoplankton Assoc. Newsl., 1:ABVI, A13-28, B28-42.

1980a. Bibliography and taxa of calcareous nannoplankton. Int. Nannoplankton Assoc. Newsl., 2:5-34.

1980b. Bibliography and taxa of calcareous nannoplankton. Int. Nannoplankton Assoc. Newsl., 2:43-81.

1981a. Bibliography and taxa of calcareous nannoplankton. Int. Nannoplankton Assoc. Newsl., 3:4-41.

, 1981b. Bibliography and taxa of calcareous nannoplankton. Int. Nannoplankton Assoc. Newsl., 3:51-86.

, 1982a. Bibliography and taxa of calcareous nannoplankton. Int. Nannoplankton Assoc. Newsl., 4:7-50.

1982b. Bibliography and taxa of calcareous nannoplankton. Int. Nannoplankton Assoc. Newsl., 4:65-92.

1983. Bibliography and taxa of calcareous nannoplankton. Int. Nannoplankton Assoc. Newsl., 5:4-13.

Wei, W., and Thierstein, H. R., 1991. Upper Cretaceous and Cenozoic calcareous nannofossils of the Kerguelen Plateau (southern Indian Ocean) and Prydz Bay (East Antarctica). In Barron, J., Larsen, B., et al., Proc. ODP, Sci. Results, 119: College Station, TX (Ocean Drilling Program), 467-494.

Wei, W., and Wise, S. W., Jr., 1989. Paleogene calcareous nannofossil magnetobiochronology: results from South Atlantic DSDP Site 516. Mar. Micropaleontol., 14:119-152. 
1990. Middle Eocene to Pleistocene calcareous nannofossils recovered by ODP Leg 113 in the Weddell Sea. In Barker, P. F., Kennett, J. P., et al., Proc. ODP, Sci. Results, 113: College Station, Texas, 639-666.

Wise, S. W., Jr., 1983. Mesozoic and Cenozoic calcareous nannofossils recovered by Deep Sea Drilling Project Leg 71 in the Falkland Plateau region, Southwest Atlantic Ocean. In Lugwig, W. J., Krasheninnikov, V. A., et al., Init. Repts. DSDP, 71, Pt. 2: Washington (U.S. Govt. Printing Office), 481-550.

Date of initial receipt: 13 August 1990

Date of acceptance: 23 November 1990

Ms 120B-201

\section{APPENDIX}

Calcareous Nannofossils Considered in This Paper in Alphabetical Order of Generic Epithets. Plate and figure numbers refer to illustrations in this paper.

Bicolumnus ovatus Wei and Wise, 1990

Calcidiscus leptoporus (Murray and Blackman) Loeblich and Tappan, 1978

Calcidiscus macintyrei (Bukry and Bramlette) Loeblich and Tappan, 1978

Chiasmolithus altus Bukry and Percival, 1971.

Chiasmolithus oamaruensis (Deflandre) Hay, Mohler and Wade, 1966

Chiasmolithus solitus (Bramlette and Sullivan) Locker, 1968

Coccolithus formosus (Kamptner) Wise, 1973

Coccolithus pelagicus (Wallich) Schiller, 1930. Plate 1, Fig. 6.
Coccolithus pelagicus floralis Wei and Wise, n. ssp., this report. Plate 2, Figs. 5-8.

Cyclicargolithus abisectus (Müller) Wise, 1973.

Cyclicargolithus floridanus (Roth and Hay in Hay et al.) Bukry, 1971. Plate 2, Fig. 4.

Discoaster lodoensis Bramlette and Riedel, 1954

Emiliania huxleyi (Lohmann) Hay and Mohler in Hay et al., 1967. Plate 1, Figs. 1 and 2.

Gephyrocapsa oceanica Kamptner, 1943. Plate 1, Figs. 3 and 4.

Helicosphaera carteri (Wallich) Kamptner, 1954

Isthmolithus recurvus Deflandre, 1954.

Pseudoemiliania lacunosa (Kamptner) Gartner, 1969

Reticulofenestra bisecta (Hay, Mohler, and Wade) Roth, 1970.

Reticulofenestra daviesii (Haq) Haq, 1971. Plate 2. Fig. 9.

Reticulofenestra gelida (Geitzenauer) Backman, 1978. Plate 1, Figs. 7 and 8.

Reticulofenestra hesslandii (Haq) Roth, 1970. Plate 2, Fig. 3.

Reticulofenestra perplexa (Burns) Wise, 1983. Plate 2, Figs. 1 and 2.

Reticulofenestra producta (Kamptner) Wei and Thierstein, 1991.

Reticulofenestra pseudoumbilica (Gartner) Gartner, 1969

Reticulofenestra reticulata (Gartner and Smith) Roth and Thierstein, 1972

Reticulofenestra samodurovii (Hay, Mohler, and Wade) Roth, 1970

Reticulofenestra umbilica (Levin) Martini and Ritzkowski, 1968

Sphenolithus conicus Bukry, 1971

Sphenolithus moriformis ( $\mathrm{Br} \times$ nnimann and Stradner) Bramlette and Wilcoxon, 1967.

Triquetrorhabdulus carinatus Martini, 1965

Zygrhablithus bijugatus (Deflandre) Deflandre, 1959 
Table 6. Distribution of Miocene-Pleistocene calcareous nannofossils in Hole 751A.

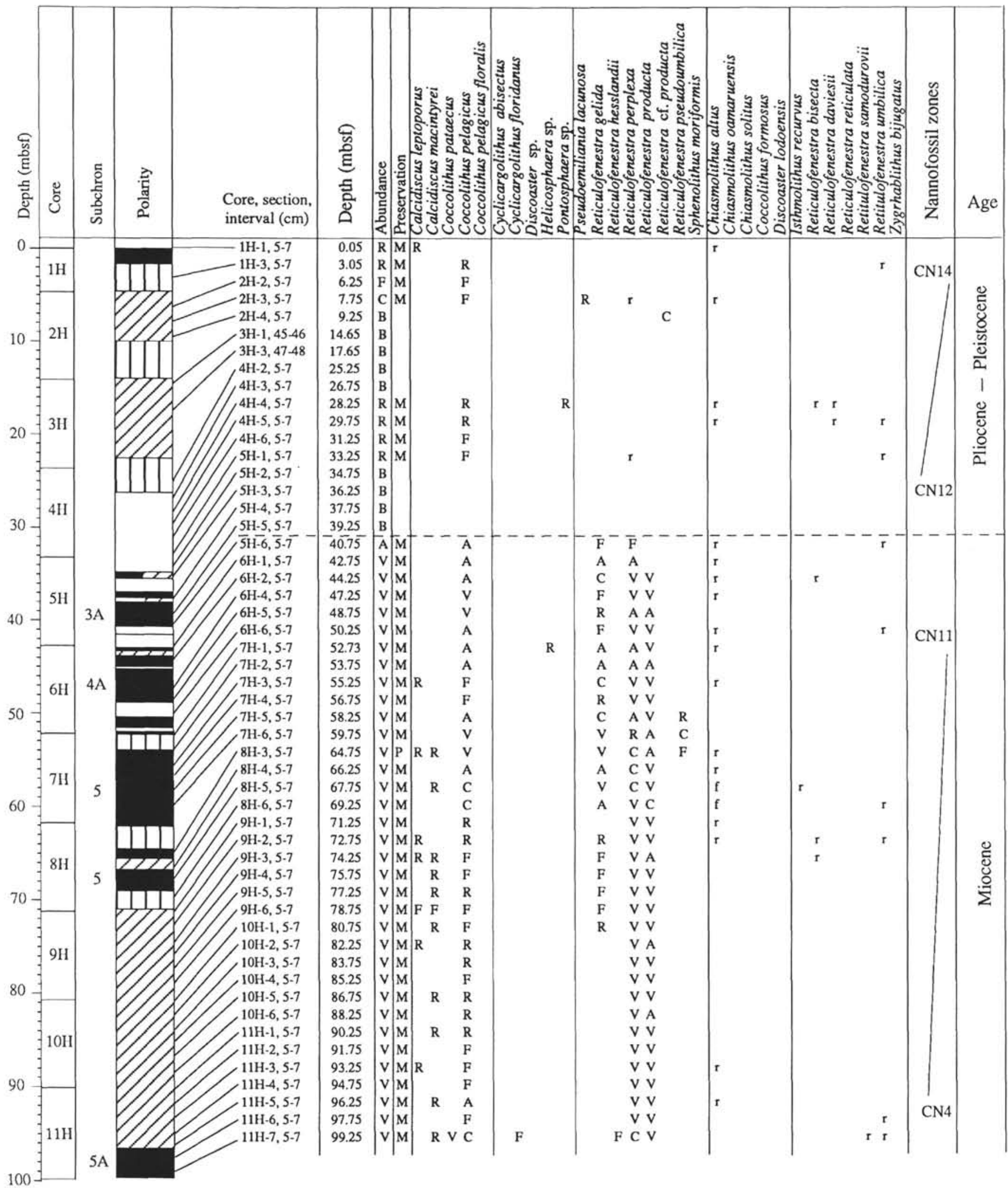

Notes: Nannofossil zones are given according to the zonation of Okada and Bukry (1980). Abundance of calcareous nannofossils is characterized by $\mathrm{V}=$ very abundant, $\mathrm{A}=$ abundant, $\mathrm{C}=$ common, $\mathrm{F}=$ few, $\mathrm{R}=$ rare, $\mathrm{r}=$ rare reworked specimens, and $\mathrm{f}=$ few reworked specimens. For preservation, $\mathrm{G}=$ good, $\mathrm{M}$ $=$ moderate, and $\mathrm{P}=$ poor. Paleomagnetic data are taken from Heider et al. (this volume). Normal paleomagnetic subchrons are shown in black, and reversed ones in white (those less reliable ones are shown in half columns). Data gaps are indicated by vertical lines and uninterpretable data by diagonal lines. 
Table 6 (continued).

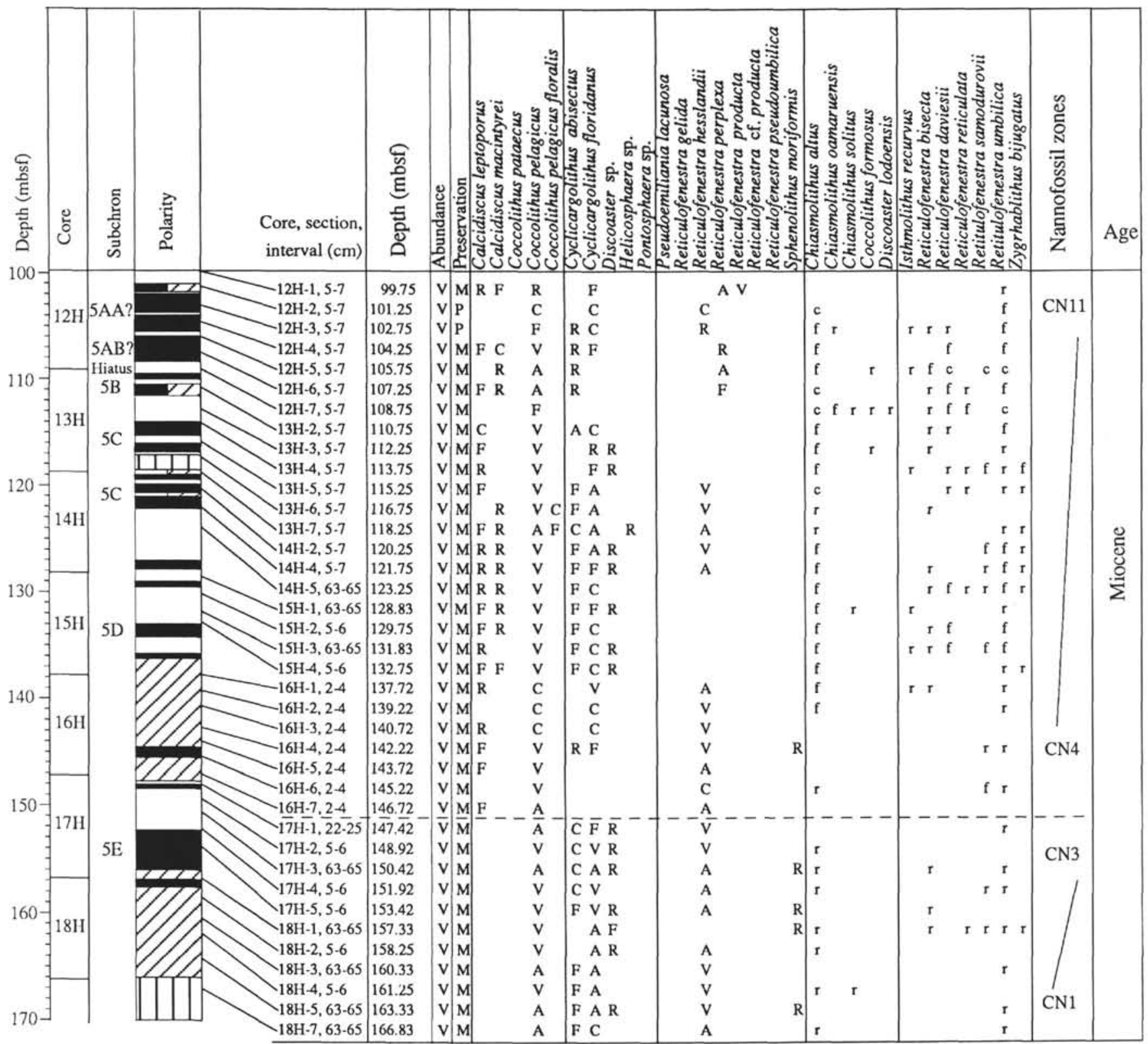

Table 7. Neogene calcareous nannofossil datum levels in Hole $751 \mathrm{~A}$ and their estimated ages.

\begin{tabular}{llrrr}
\hline \multicolumn{1}{c}{ Species event } & \multicolumn{1}{c}{$\begin{array}{c}\text { Core, section, } \\
\text { interval }(\mathrm{cm})\end{array}$} & Depth (mbs) & $\begin{array}{r}\text { Age } \\
(\mathrm{Ma})\end{array}$ & Source \\
\hline LO Reticulofenestra gelida & $5 \mathrm{H}-5,5 / 5 \mathrm{H}-6,5$ & $39.25-40.75$ & 3.8 & 1 \\
LO Reticulofenestra hesslandii & $11 \mathrm{H}-6,5 / 11 \mathrm{H}-7,5$ & $97.75-99.25$ & 11.1 & 1 \\
FO Calcidiscus leptoporus & $16 \mathrm{H}-7,2 / 17 \mathrm{H}-1,22$ & $146.72-147.42$ & 18.2 & 1 \\
\hline
\end{tabular}

Notes: 1 = Wei and Thierstein (1991) and Barron et al. (1991).
Table 8. Magnetostratigraphically calibrated ages of calcareous nannofossil datums at Site 747, 748, and 751 .

\begin{tabular}{lrrr}
\hline \multicolumn{1}{c}{ Species event } & Site 747 & Site 748 & Site 751 \\
\hline LO Reticulofenestra gelida & $3.3 \mathrm{Ma}$ & $3.4 \mathrm{Ma}$ & $<5.8 \mathrm{Ma}$ \\
LO Reticulofenestra hesslandii & $11.6 \mathrm{Ma}$ & $11.7 \mathrm{Ma}$ & $11.7 \mathrm{Ma}$ \\
FO Calcidiscus leptoporus & $18.0 \mathrm{Ma}$ & $18.1 \mathrm{Ma}$ & $18.1 \mathrm{Ma}$ \\
LO Reticulofenestra bisecta & $23.9 \mathrm{Ma}$ & & \\
LO Chiasmolithus altus & $27.7 \mathrm{Ma}$ & & \\
\hline
\end{tabular}

Note: Magnetostratigraphic data are taken from Heider et al. (this volume) and Inokuchi and Heider (this volume). 

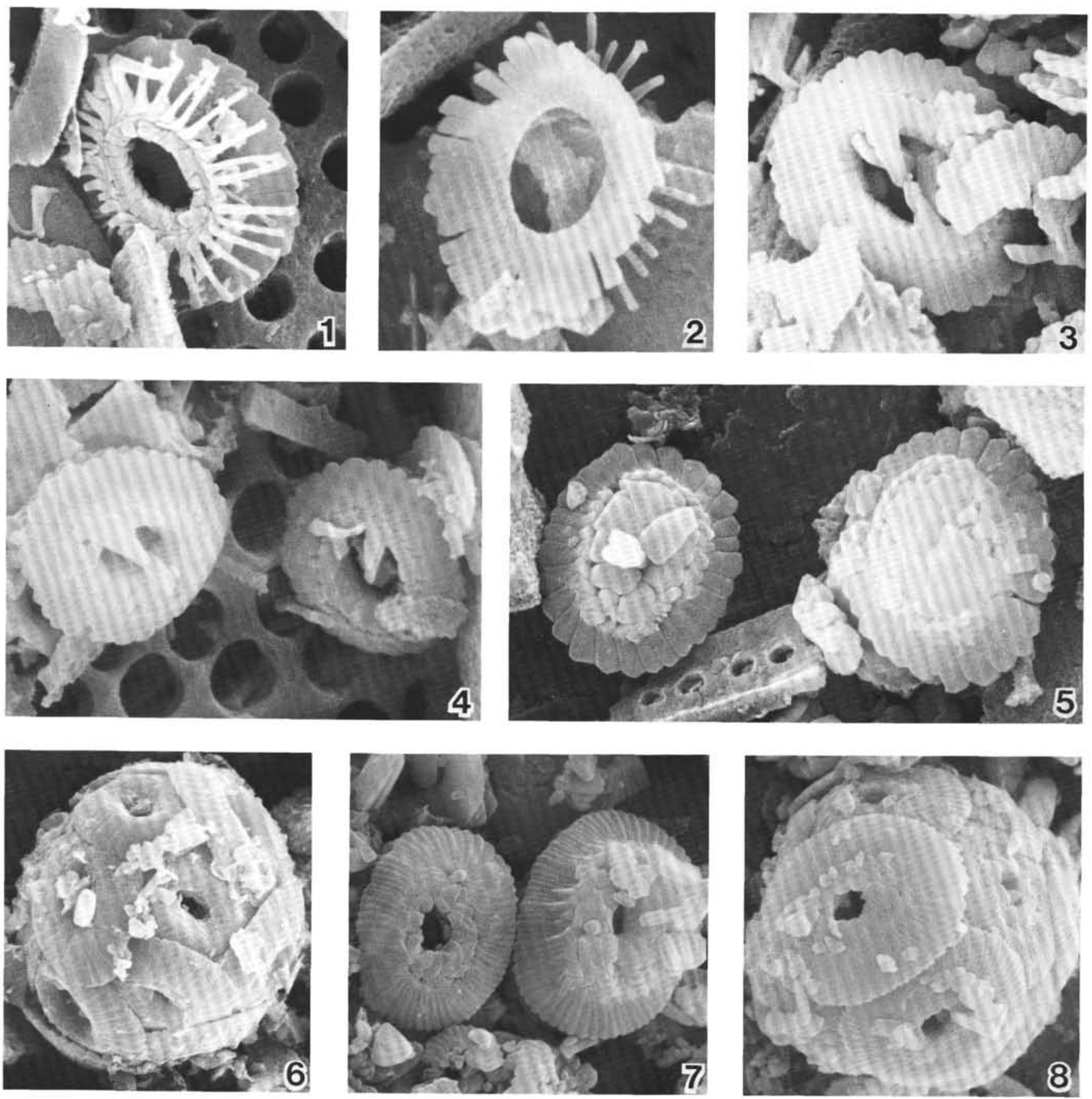

Plate 1. 1-2. Emiliania huxleyi (Lohmann) Hay and Mohler, Sample $120-747 \mathrm{~A}-1 \mathrm{H}-1,58-62 \mathrm{~cm} .(1) \times 11,000 ;(2) \times 17,000$. 3-4. Gephyrocapsa oceanica Kamptner, Sample 120-747A-1H-4, 10-11 cm. (3) $\times 14,000 ;(4) \times 12,000$. 5. Reticulofenestra sp. cf. producta (Kamptner) Wei and Thierstein, Sample 120-747A-3H-4, 10-11 cm. 6. Coccosphere of Coccolithus pelagicus, Sample 120-747A-3H-4, 10-11 cm, $\times 2,700$. 7-8. Reticulofenestra gelida (Geitzenauer) Backman, Sample 120-747A-6H-4, 10-11 cm. (7) $\times 4500$; $(8) \times 3300$. 

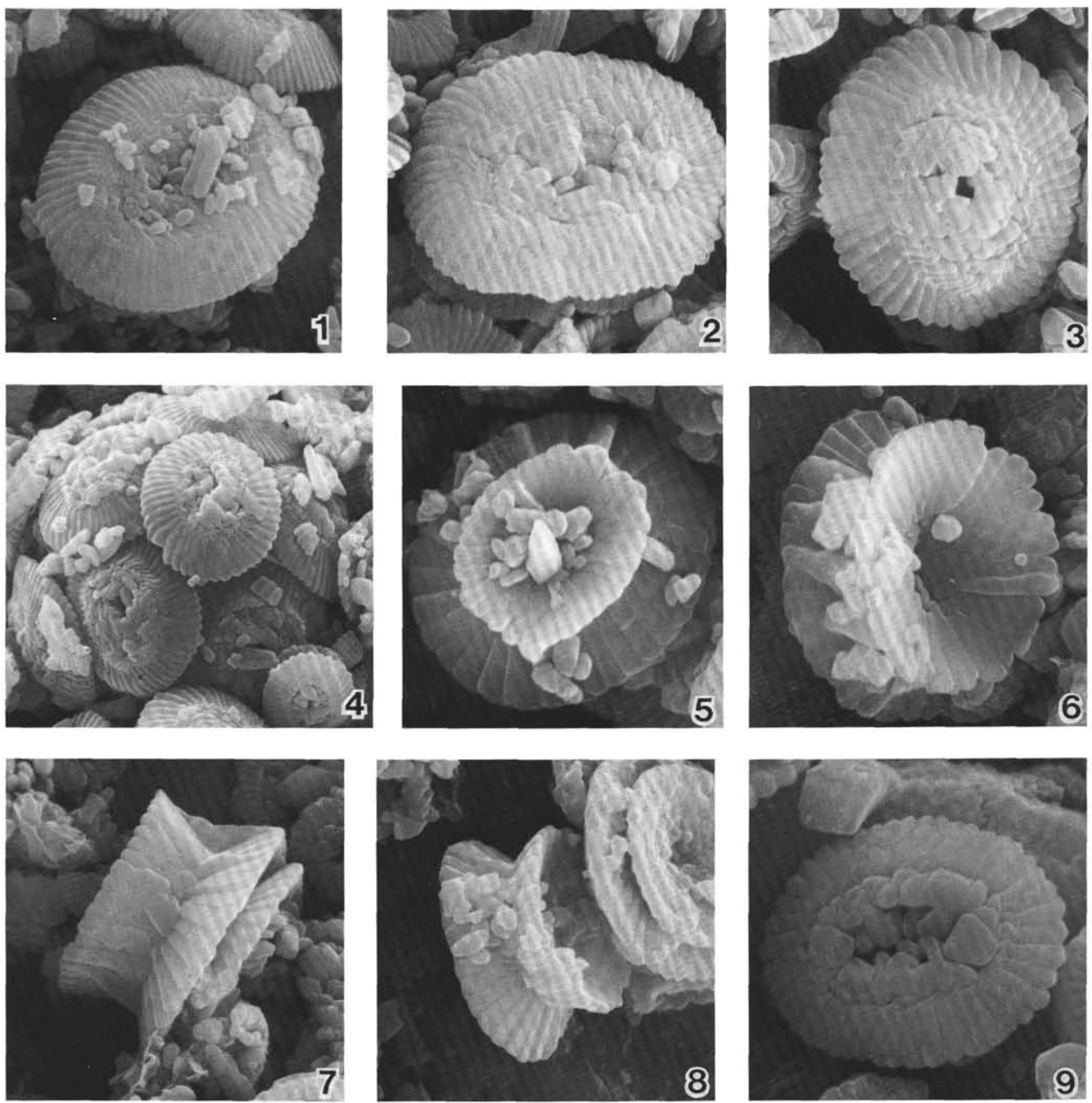

Plate 2. 1-2. Reticulofenestra perplexa (Burns) Wise, Sample $120-747 \mathrm{~A}-6 \mathrm{H}-4,10-11 \mathrm{~cm}$. (1) $\times 5000$; (2) $\times 6500$. 3. Reticulofenestra hesslandii (Haq) Roth, Sample 120-747A-9H-2, 58-62 cm. 4. Coccosphere of Cyclicargolithus floridanus (Roth and Hay) Bukry, Sample 120-747A-9H-2, 58-62 cm. 5-8. Coccolithus pelagicus floralis Wei and Wise, n. ssp., Sample 120-747A-14H-2, 10-11 cm. (5) $\times 8000$, isotype; (6) $\times 6500$, isotype; (7) $\times 7000$, holotype; (8) $\times 5000$, isotype. 9. Overgrown specimen of Reticulofenestra daviesii (Haq) Haq, Sample 120-747A-17H-1, $10-11 \mathrm{~cm}, \times 9500$. 